\title{
PUBLIC PARTICIPATION, ARTISANAL FISHERS, AND THE IMPLANTATION OF A COASTAL MEGAPROJECT
}

\section{Participação pública, pescadores artesanais e a implantação de um megaprojeto costeiro}

\author{
John Marr Ditty \\ Mestre em Políticas Sociais, Universidade Estadual do Norte Fluminense \\ john_ditty@hotmail.com \\ Carlos Eduardo de Rezende \\ Professor Titular, Centro de Biociências e Biotecnologia, \\ Universidade Estadual do Norte Fluminense. Bolsista CNPq \\ rezende@uenf.br
}

Artigo recebido em 04/10/2012 e aceito para publicação em 17/12/2012

\begin{abstract}
The present study seeks to identify the perceptions of the marine artisanal fishers of the community of Farol de São Tomé in the municipality of Campos dos Goytacazes, RJ, Brazil, regarding the political decision-making process regulating the implantation of the Açu Superport Industrial Complex (ASIC). The marine artisanal fishery in this community may be threatened by the size and scope of the ASIC, which is to be the largest industrial port complex in Latin America. Data were gathered through interviews with open-ended questions conducted among 13 active marine fishers within the community of Farol de São Tomé. The results of the study indicate that although the fishers desired participation in the ASIC's licensing process, there were insufficient opportunities for such participation and that fishers are suspicious of the motives guiding decisions affecting their region. Fishers also predict adverse changes to their activities. In order to debate operational questions relating to the ASIC we recommend that public hearings be held in the community of Farol de São Tomé.
\end{abstract}

Keywords: artisanal fishers, megaproject, public participation

RESUMO: O presente estudo buscou reidentificar as percepções dos pescadores marinhos artesanais da comunidade do Farol de São Tomé, município de Campos dos Goytacazes-RJ, Brasil, referentes ao processo decisório político frente à implantação do Complexo Portuário Industrial do Açu (ASIC). A pesca marinha artesanal pode estar ameaçada pelo tamanho e escopo do ASIC, que será o maior complexo portuário e industrial da América do Sul. Dados foram coletados através de entrevistas com perguntas abertas entre 13 pescadores marinhos ativos na comunidade do Farol de São Tomé. Os resultados do estudo indicam que, mesmo querendo participar no processo de licenciamento do ASIC, os profissionais da pesca não tiveram oportunidades suficientes para tal participação e que a maioria dos pescadores desconfia dos motivos que nortearam as decisões na sua região. Os pescadores também preveem mudanças adversas às suas atividades. Para debater questões operacionais do ASIC recomenda-se a realização de audiências públicas na comunidade do Farol de São Tomé.

Palavras-chaves: pescadores artesanais, mega empreendimento, participação pública 


\section{INTRODUCTION}

The world today is marked by the implantation of megaprojects that perform diverse industrial and logistical functions in the same location, thus reflecting the interconnectivity of the global market. Such projects are characterized by the use of raw materials that come from afar with the objective of supplying distant markets with semi-finished products. In terms of social policy, the very large physical areas utilized, the diversity of activities engaged in, and the likelihood of socio-environmental impact require that authorities exercise great caution during the process of a megaproject's licensing and implantation. In this regard, various studies have demonstrated that environmental ills tend to accumulate disproportionately and inequitably among the most vulnerable segments of society (BULLARD, 1994; AGYEMAN and EVANS, 2003; AGYEMAN, 2005; MARTÍNEZ ALIER, 2007; ACSELRAD, 2008) and that policies related to the licensing of megaprojects should encourage the collaborative participation of all stakeholders of the regions involved (FLYVBJERG et tal., 2003).

Public deliberation was already a mainstay of ancient Greece, and Rousseau later maintained that participative democracy was an effective means for the mitigation of the excesses of certain powerful individuals and groups (ROUSSEAU, 1997). Nevertheless, there are different kinds of 'public participation.' Arnstein states that a process of participation devoid of a meaningful redistribution of power will only allow the authorities to claim the existence of a democratic process that in fact only serves to consolidate the benefits of the few (ARNSTEIN, 1969). In her opinion, meaningful participation only begins to occur once citizens not only speak, but are also heard and acquire the power of negotiation. Benjamin Barber likewise argues that what defines democracy is above all the process, and that this process depends on the consensus derived from numerous encounters that are replete with debate and deliberation and in which every voice is heard (BARBER, 2011).

The decision to involve all stakeholders in environmental planning or the licensing process for a proposed megaproject may be grounded in philosophical or pragmatic considerations (WEBLER et al.,
1995; RANDOLPH, 2004). In addition to upholding democratic principles, the inclusion of public participation in planning and licensing can be related to sustainability objectives (SZARO et tal., 1998; ROSELAND, 2000; AGYEMAN, 2005; ZHOURI, 2008). Agyeman (2005) and Roseland (2000) maintain that achieving environmental sustainability requires the existence of sustainable communities, and that such communities cannot exist without meaningful public participation. Art. 225 of the Brazilian Federal Constitution of 1988 likewise envisions symbiosis between sustainability and public engagement:

All have the right to an ecologically balanced environment, which is an asset of common use and essential to a healthy quality of life, and both the Government and the community shall have the duty to defend and preserve it for present and future generations (BRASIL, 1988).

Participative processes have been identified as a means of reducing problems of injustice and inequality. Some theoreticians argue that distribution, recognition, and participation are three requisites of justice (AGYEMAN and EVANS, 2003; SCHLOSBERG, 2004; AGYEMAN, 2005). For Nancy Frasier (1996), however, there must be two 'participative parities' in order to achieve justice. The first of these two pillars requires society's recognition of the intrinsic value of the social actors involved; the second relates to an equitable distribution of benefits within society. Called 'objective' and 'intersubjective' preconditions, respectively, the former guarantees the independence and 'voice' of the actor, while the latter assures institutional respect in favor of equal opportunities for the appropriation of social dignity (FRASER, 1996).

Roseland also considers the full and active participation of citizens the factor that distinguishes sustainable from unsustainable communities. According to this author, without participation there will be no efficient use of urban space, reduction in the consumption of natural capital, or multiplication of social capital (ROSELAND, 2000, p. 105).

Less theoretical approaches have also identified benefits derived from the use of participative processes in a context of natural resource management.

Soc. \& Nat., Uberlândia, 25 (1): 51-60, jan/abr/2013 
According to many researchers, such processes tend to be characterized by high levels of competence in the quality of decisions made, increased understanding of the motives that affect the decisions obtained, and the perception in the stakeholder communities of higher levels of legitimacy of those decisions (WEBLER et tal., 1995; SCHLOSBERG, 2007; ZHOURI, 2008; THABREW et tal., 2009). In a study of the conflict between the local population and commercial entities for forest resources in Senegal, Jesse Ribot (1995) found that vested interests used 'participation' as merely a slogan to help perpetuate unjust practices and recommended more meaningful participatory schemes as a remedy for such subterfuge.

According to Zhouri (2008), "in terms of the population's participation in the process of environmental licensing, Public Hearings constitute the only formal moment in which participation is scheduled during the entire process" (ZHOURI, 2008, p. 103, translation mine). For this author, however, public hearings often present numerous obstacles to the meaningful participation of the population, such as a lack of transparency in the process, the use of information and documents to which access requires previous and formal solicitation and that marginalize laypersons with their use of highly technical terms and language, and the absence of formal mechanisms by which feedback can be provided to citizen participants. Given that, still according to Zhouri (2008), these hearings are customarily only scheduled after decisions and accords have already been formalized between public authorities and entrepreneurs, they represent "formalization of the process of environmental licensing, a simulation of democratic and participative procedures" (ZHOURI, 2008, p. 103, translation mine).

Another aspect of public hearings that tends to hinder meaningful citizen participation concerns their organization. These hearings are generally held during the evenings or at night, begin with a lengthy presentation by the developers, federal and/or state environmental regulatory agencies, and environmental impact assessment agency, are interrupted by a snack break, and only then begin to accept questions and statements of opposition from citizens and participatory entities. This organizational structure tends to lead participants to a state of fatigue and apathy that effectively inhibits an understanding of the socio-environmental alterations at stake and reduces the likelihood of fruitful discussion or debate.

It is against this backdrop that the Açu Superport Industrial Complex (ASIC) has initiated its implantation and scheduled the beginning of its industrial and logistical operations for 2012. Sanctioned by São João de Barra, RJ, Municipal Law n ${ }^{\circ} 035 / 06$, the ASIC has at its disposition an area of 7,800 ha, thus rendering it the status of the planet's second largest port complex, only surpassed by the Port of Rotterdam (COUTINHO, 2009). According to the official site of the ASIC (LLX, 2011), the complex:

will receive two steel mills, two cement factories,
a power generation complex, an automaker, auto
parts industries, a metallurgical center, a termi-
nal for the storage and processing of oil, and an
offshore support services and IT complex, amoun-
ting to investments of more than U\$ 40 billion and
creating approximately 50 thousand new jobs in
the region (LLX, 2012).

Considering the socioeconomic transformations that are occurring in the region, the ASIC will almost certainly trigger both positive and negative effects. In a study on the perceptions of the consequences of the complex among the residents of São João da Barra, the host municipality of the project, Kury et tal. (2010) obtained results in which $56 \%$ of those interviewed predict changes such as "industrialize the region" or "benefit the population," while $41 \%$ expect the complex to "harm the population" or "pollute the environment" (KURY et al., 2010, p. 11, translation mine).

The community of Farol de São Tomé, 20 $\mathrm{km}$ from the ASIC along the coast, whose principal economic activities are directly and indirectly related to marine artisanal fishery, and which has a fishers colony with up to 1,200 registered members (VIANNA, 2009), therefore, is the home to social actors with strong stakes in the eventual elaboration of this megaproject. It is worth noting that there have been no other studies to date on the perspectives of the fishers of Farol de São Tomé with respect to the alterations posed by the ASIC, which is a cause for concern given 
the potential for social upheaval and negative impact that the ASIC represents for the region's marine fishery and environment. Coutinho (2009) identified alterations related to the installation of the ASIC such as:

Modifications of the morphology of the coast; modifications of the patterns of marine currents; alteration or loss of the superficial soil layer; reductions in local fauna and flora; the appearance of invasive biological organisms; the exclusion of other economic uses in the region; alterations in the natural characteristics of the air, sea, rivers, and other environments (COUNTINHO, 2009, p. 52, translation mine).

In addition to changes stemming from construction of the ASIC, alterations related to its operational status were also identified. These included:

the occurrence of environmental degradation, whether resulting from accidents or not; the generation and on-site disposal of solid waste products; chronic accidental contamination coming from cargos; the introduction of invasive organisms into the environment; and pollution in the form of diverse sources of liquid discharge (COUTINHO, 2009, p. 52, translation mine).

Therefore, the present work sought the perceptions of the marine fishers of Farol de São Tomé with respect to the licensing process of the ASIC. The study was guided by two research questions: 1) From the point of view of the marine fishers of Farol de São Tomé, to what extent were there opportunities for participation in the political decision-making process concerning the ASIC? 2) How do the fishers characterize this process?

\section{METHODS}

This study was carried out in the community of Farol de São Tomé (22 2' 11' S and 41 3' 1' W) located on the coast of the municipality of Campos dos Goytacazes, $45 \mathrm{~km}$ from the city center of Campos, in northern Rio de Janeiro State, Brazil. According to the Brazilian Institute of Geography and Statistics (IBGE, 2010), the population of the municipality of Campos dos Goytacazes is 463,545 inhabitants.

Thirteen interviews with marine fishers were carried out on February 18 and 19, 2012. Whenever possible, in order to minimize the interference of others and to encourage an atmosphere in which opinions could be freely expressed, interviews were conducted in the presence of only the fisher and the interviewer. The interviewer presented himself as a researcher of a local university who sought the opinions of the marine fishers of Farol de São Tomé on the transformations occurring in the region as a result of the ASIC. The interviews followed a pre-established sequence, taking the form of informal conversations. Interviewee responses were written down immediately after each interview. There were responses lacking for one or two query areas in a few interviews.

The survey script was composed of three general query areas. The first was related to the degree of importance that fishers placed on their hypothetical participation in the decision-making process. In this regard, the following questions were employed: Do you consider it important for fishers to be involved in the licensing process of the Açu Superport? Why? Have you noticed any changes in fishery since the beginning of the construction of the Superport? What were they?

The second query area investigated the existence of concrete opportunities for the participation of fishers in the planning and licensing of the ASIC. Therefore, it utilized the questions: Did anyone seek your opinion at any time during this process? Who? Were public hearings held? Did you attend? Why? If you didn't attend, would you, and why?

The last area investigated sought to verify the level of satisfaction held by the fishers with respect to the political decision-making process of the ASIC. The questions were: What is your general opinion about the way in which the Açu Superport's licensing process was conducted? Why?

\section{RESULTS}

All those interviewed were males between approximately 35 and 60 years of age. Twelve of the 
thirteen fishermen (92\%) currently fish actively, and the only fisherman who no longer actively participates in fishery currently works buying and selling fish. One fisher $(8 \%)$ divides his activities between marine and inland freshwater fishery. During four interviews (31\%), at least one of the three query areas had no response.

With respect to the importance of fisherman participation in the ASIC licensing process, eleven fishermen $(85 \%)$ registered their opinions. Of these eleven, ten $(91 \%)$ responded unequivocally and said that their participation is important (Figure 1). This position was justified by responses such as "Fishermen may be harmed by the complex," "The construction is going to wreak havoc on the sea," etc.

Of the ten fishers who responded to the question, six $(54 \%)$ have detected negative changes in their fishery since work on the project began in 2007. Some maintained that the exclusion zone established around the breakwaters and pier that extends $3.6 \mathrm{~km}$ into the ocean has precluded their activities in the most valuable reproduction site of the Atlantic seabob (Xiphopenaeus kroyeri). Others associated reduced fishing yields of species inhabiting waters close to the coastline, such as shark, corvina (Micropogonias furnieri), sea catfish, guachanche barracuda (Sphyraena guachancho), and sea trout with the Superport. Others claimed to have detected changes without specifying what they were.

Among the four fishers who responded to the question and have not noticed alterations in their fishery, all four reported concern about the future viability of their activities in Farol de São Tomé. Among the reasons cited for such concern were the possibility of increased risk of accidents that could affect environmental quality and the predicted transit of large ships in the region that could reduce their access to fishing areas. The only fisherman who considered the participation of fishers in the licensing process as merely "somewhat important" justified his position by stating that in meetings authorities "only make promises that aren't kept," thus maintaining that events of this type are not useful.

Of the thirteen fishers who answered the question, ten $(77 \%)$ responded that no public hearings on the ASIC had been held and that their opinions on the subject had not been solicited by any agency or entity.
Of these ten, eight fishermen registered opinions as to whether they would attend public hearings if given the opportunity, and all eight answered affirmatively. Three interviewees $(23 \%)$ responded that there had in fact been a public hearing and/or meeting with fishermen about possible changes to the environment caused by the ASIC. According to these fishers, this meeting was held at the Clube Náutico of Farol de São Tomé and included the presence of several Petrobrás employees. All three of these fishermen attended this meeting.

Nine fishers offered opinions that characterized the licensing process with respect to the Açu Superport Industrial Complex, and all considered this process negative. Typical responses on this item complained of the absence of fisher participation in this process, opined that this process was "rigged for the benefit of the rich," for the benefit of employees of the Z-19 fishermen's group, or that fishermen would be forcibly barred from their activities in much the same way that "small farmers are losing their land in Açu." Some fishermen did not characterize the process in a specific way, merely opining that the process was "bad because it dealt the fishermen a losing hand".

\section{DISCUSSION}

Despite the economic importance that their activity represents for their community, the fishers of Farol de São Tomé are a particularly vulnerable social group. Through the use of questionnaires in Farol, Feres (2010) verified extremely low levels of income and education among the fishers. The fact that all the fishers interviewed in the present study were males of between approximately 35 and 60 years of age suggests that the marine fishery of the community of Farol de São Tomé is an economic activity practiced principally by men who have already reached middle age and who might therefore have difficulty substituting this activity with another. Many identified themselves as heads of family who struggle to provide for their wives and offspring. Many also claimed to have been born in Farol de São Tomé into fishermen families, a fact which suggests strong multigenerational value related to fishery in terms of identity.

The results demonstrate overwhelming consensus among Farol's fishermen that because the 
decisions made could influence or define the future of their activities, fishers should have been involved in the licensing process of the ASIC. Of the eleven fishers who offered an opinion, ten $(91 \%)$ responded that the fishermen should play a role in this process. Yet even the one fisherman who didn't answer an unequivocal "Yes" did not answer "No," instead responding that it was "somewhat" important for fishermen to be a part of the process. Therefore, no fisher responded that the fishermen should not be a part of the licensing process.

The reason given for why the fishers should be involved in the political decision-making process always cited vulnerability of fishery activities in the face of the ASIC's implantation. Given that the great majority of the fishermen interviewed have more than 20 years experience working within the same ecosystem, the concern expressed by these professionals for the future health of the coastal ecosystem off Farol de São Tomé should be understood as a warning signal.

It is important to note that the only fisher who responded that fishermen involvement was only "somewhat important" exhibited symptoms of alienation with respect to the process because, in his view, authorities make promises in public hearings that are not kept and because, regardless of participation in hearings, he predicts for the fishers of Farol de São Tomé a fate similar to that of the small farmers who were removed from Açu against their will (BALBI, 2012). This sentiment may be related to the finding cited previously that public hearings typically merely constitute ceremonies for the ratification of pre-established accords (ZHOURI, 2010) and thus are not designed to involve stakeholders to any meaningful degree.

Ten of the thirteen fishers responded that no public hearings on the ASIC were held and that their opinions were never sought during the licensing process. Three fishers $(23 \%)$ answered that at least one meeting or public hearing had occurred, but confirmed that their opinions had not been solicited directly. Therefore, all those interviewed confirmed a lack of any direct opinion poll or survey among the fishing community. Five fishers cited a public hearing held in the Clube Náutica of the Farol de São Tomé with the presence of representatives of Petrobras, IBAMA (the Brazilian Institute of the Environment and Natural Resources), and the Minister of Fishery.
However, while three of the fishers remember this meeting as a hearing related to the installation of the ASIC, two fishers affirmed that this meeting did not discuss the ASIC.

There was in fact a public hearing held by IBAMA at the location specified on November 6 , 2010, but the agenda of this meeting involved the environmental impact assessment of the Petroleum and Natural Gas Production and Outflow System of models 3 (P-55) and 4 (P-62) of the Roncador Petroleum Field. The public hearings that actually dealt with environmental impact related to the Açu Superport Industrial Complex were held in São João da Barra, Campos dos Goytacazes, and Rio de Janeiro on January 11, 2011, September 2, 2011, and September 13, 2011, respectively, and never in the community of Farol de São Tomé.

It is thus possible to advance two possibilities about the participation of Farol de São Tomé fishers in public hearings. First, fishers were not adequately informed of the existence of the public hearings that involved the ASIC. Given their economic interests and the possibility of the ASIC impacting their livelihood, this would represent a failure of government and Fishers Colony Z-19 representatives. Second, it is possible that the fishers knew of the public hearings and denied this knowledge during interviews, possibly motivated by a desire to reap financial reparations. Yet while fishers would have a clear motive for such deception, it hardly seems likely that $77 \%$ of the interviewees would have adopted the same strategy. Moreover, some of the fishermen who denied knowing about the public hearings reported detecting no changes in their fishery, thereby forfeiting a much more obvious and compelling argument in favor of a need for direct payments to fishers. Again, it seems highly unlikely that such an economically and socially underprivileged group as artisanal marine fishers would have lied in claiming to have been denied opportunities for participation while honestly admitting to unaffected fishing yields.

The fact that some fishermen were unclear as to the purpose of a public hearing which they attended 15 months before signals grave problems in the manner in which decisions and policies are presented to laypersons. This situation represents a squandering 
of the local knowledge of those very social actors who have most experience with the routine management of an ecosystem and an inability to effectively promote the participation of all stakeholders. Several fishers reported signing a document at that hearing, but without any clear understanding of what they were signing, either because of the use of highly technical terms and language in the document or due to a limited ability to understand written Portuguese. Two fishermen reported feeling pressure to sign this document, which they did partly out of fear of reprisals for not doing so.

All fishermen who responded $(\mathrm{n}=11)$ expressed dissatisfaction with the way the political decision-making process related to the ASIC licensing was conducted. Common sentiments were of impotence and frustration before this process resulting from the unequal economic status of the fishers in relation to the parties promoting the ASIC, their relatively low numbers when compared with citizens who hoped to benefit directly or indirectly from the project, and their limited political influence especially when one considers that several high-ranking state and municipal elected officials publically declared their support for the ASIC. It is important to reflect that LLX is part of the EBX Group, which was founded and is $61 \%$ owned by Eike Batista, Brazil's richest man (FORBES, 2012), and whose power in Brazil has been considered second only to that of Brazil's President (BLANKFELD, 2010). This context may help shed light on charges that the local fishers colony is failing to represent the true interests of its constituents, as the only investments or payments made by LLX to date in Farol de São Tomé directly benefited the Z-19 Fishers Colony itself in the form of purchasing and remodeling its main office building. This fact is in stark contrast to the situation in São João da Barra, where fishers based roughly the same distance from the ASIC have received professional training programs, a US $\$ 1.4$ million fishing depot, an IT laboratory, and free dental care (LLX, 2012).

The sensation of abandonment registered among the fishers could contribute to future negative management practices with respect to the coastal ecosystem. Garrett Hardin described the 'Tragedy of the Commons,' a situation in which actors knowingly make rational, calculated decisions out of self-interest which are profitable in the short-term but will ultimately decimate a resource on which many depend (HARDIN, 1968). In this regard, some fishers commented that with the reduction in the fishing yields of economically important species and the difficulty with which economic commitments are met during the annual shrimp fishing prohibition between March 1 and May 31, illegal fishery during this period may increase.

The results demonstrate that almost all the fishers share very similar views in terms of the three areas of inquiry. Because they have already detected or expect future negative changes to the fishery that occurs in Farol de São Tomé, fishers want to be involved in the political decision-making processes referent to the ASIC. Opportunities to express their opinions, share their knowledge of the coastal ecosystem, request clarification, or even register their disapproval were inexistent or lacking. The artisanal fishers are skeptical that the process was truly designed for the incorporation of their opinions or for affected communities to influence policy.

Such results indicate serious shortcomings in the design and scope of the ASIC's licensing process. Therefore, in order to promote sustainability, an explicit objective of the 1988 Constitution, we urge the development of policies that will foster the meaningful participation of the fishers of Farol de São Tomé. Such policies should make use of widely publicized public hearings held in the community of Farol de São Tomé and be based on strategies that that promote bottom-up deliberative schemes, enhanced transparency, and the involvement of the human capital of the stakeholders. Although the licensing of the ASIC has been concluded, the community of Farol de São Tomé should be involved in deliberations on the future functioning and risks of the ASIC itself, as well as the operations involving the use of Farol de São Tomé's coastal waters by tankers and cargo ships.

\section{CONCLUSION}

The frameworks of Environmental Justice and Just Sustainability have demonstrated the inequitable nature by which environmental risk tends to accumulate in underprivileged communities, even as these 
same communities tend to be deprived of access to valuable natural resources to a much higher degree than wealthier populations. Concurrently, many studies have verified the value of public participation in the development and execution of socially equitable public policy and environmental planning.

The results of this study demonstrate a perception of vulnerability on the part of fishers with respect to the artisanal fishery practiced in Farol de São Tomé given the establishment of an industrial megaproject in the coastal region. The licensing process of the ASIC effectively excluded the marine fishers from public hearings and the opinions of these stakeholders were not solicited. The study registered a sensation of powerlessness on the part of the fishers before the corporate interests involved and the perception of collusion between elected policy-makers and entrepreneurs.

Given the fishers' experience in dealing with the coastal ecosystem, their potential as human capital in deliberations about the future of the region and the true vulnerability of their activity while faced with the extensive socio-environmental reconfigurations in play, the exclusion of these professionals from the political deliberative process is regrettable. We urge that public hearings be scheduled in the community of Farol de São Tomé in order to promote the participation of the marine artisanal fishers in the operational questions related to the ASIC and that these hearings be carefully structured in order to maximize equity, transparency, and access to community insight.

\section{ACKNOWLEDGEMENTS}

The authors wish to thank CAPES (Coordenação de Aperfeiçoamento de Pessoal de Nivel Superior) for providing the fellowship that helped make this study possible.

\section{REFERENCES}

ACSELRAD, H. O que é justiça ambiental. Rio de Janeiro: Garamond, 2008.

AGYEMAN, J.; EVANS, T. Toward just sustainability: building equity rights with sustainable solutions. In: The Annals of the American Academy of Polit- ical and Social Science, 590: 35, p. 35-53, November 2003. Boston: Sage, 2003.

AGYEMAN, J. Sustainable communities and the challenge of environmental justice. New York: New York University Press, 2005.

ARNSTEIN, S. A ladder of citizen participation. JAIP, Vol. 35, No. 4, July 1969. P. 216-224.

BALBI, A. Produtor rural é detido em desapropriação no Açu. Globo.com, 13 March 2012. Available at: <http://oglobo.globo.com/economia/produtor-rural-detido-em-desapropriacao-no-acu-4302226>. Accessed 24 May 2012.

BARBER, B. Occupy wall street: 'we are what democracy looks like!'. Logos Journal, Vol. 10, Issue 4, 2011. Available at: <http://logosjournal.com/2011/ fall_barber/>. Accessed 8 Mar 2012.

BLANKFELD, K. Eike Batista: Brazil is home to majority of South America's most powerful. Forbes. com, 4 Nov 2012. Available at: <http://www.forbes. com/sites/kerenblankfeld/2010/11/04/eike-batistabrazil-is-home-to-majority-of-south-americas-mostpowerful/>. Accessed 23 May 2012.

BRASIL. Constituição (1988). Constituição da República Federativa do Brasil. Brasília, DF: Senado, 1988. Available at: < http://pdba.georgetown.edu/ Constitutions/Brazil/english96.html>. Accessed 14 May 2012.

BULLARD, R. Environmental justice for all: it's the right thing to do. 9 J. Envtl. L. \& Litig., 1994. P. 281-282.

COUTINHO, R. R. Avaliação das transformações socioambientais oriundas da implantação do complexo portuário industrial do Açu. (Master's Dissertation) Campos dos Goytacazes: IFF, 2009.

FERES, S. A percepção dos pescadores artesanais do Farol de São Tomé sobre as políticas públicas. In: CONGRESSO FLUMINENSE DE INÍCIAÇÃO 
CIENTÍFICA E TECNOLÓGICA, 2010. Anais... Campos dos Goytacazes: IFF, 2010.

FLYVBJERG, B; BRUZELIUS, M.; ROTHENGATTER, W. Megaprojects and risk: an anatomy of ambition. Cambridge: Cambridge University Press, 2003.

FORBES. Eike Batista. Available at: <http://www. forbes.com/profile/eike-batista/>. Accessed 23 May 2012.

FRASER, N. Social justice in the age of identity politics: redistribution, recognition, and participation. In: THE TANNER LECTURES ON HUMAN VALUES, April 30-May 2 1996, Annals... Stanford University. Palo Alto: Stanford University Press, 1996.

HARDIN, G. The tragedy of the commons. Science, New Series, Vol. 162, No. 3859, 13 Dec. 1968. p. 1243-1248.

IBGE, 2010. Censo demográfico de 2010. Fundação Instituto Brasileiro de Geografia e Estatística. Dados referentes ao município de Campos dos Goytacazes. Available at: $<$ http://www.ibge.gov.br/home/estatistica/populacao/censo2010/tabelas_pdf/total_populacao_rio_de_janeiro.pdf $>$. Accessed 11 Mar 2012.

LLX. Açu Superport Industrial Complex. Available at: <http://www.llx.com.br/cgi/cgilua.exe/sys/start. htm?sid=224\&lng=us $>$. Accessed 15 May 2012.

LLX. Açu superport socio-environmental projects. Available at: $<$ http://www.llx.com.br/cgi/cgilua.exe/ sys/start.htm?sid=320\&lng=br $>$. Accessed 20 May 2012.

MARTÍNEZ ALIER, J. O ecologismo dos pobres. São Paulo: Contexto, 2007.

RANDOLPH, J. Environmental land use planning and management. Washington D.C.: Island Press, 2004.

RIBOT, J. From exclusion to participation: turning Senegal's forestry policy around? World Development, Vol. 23, No. 9, 1995. p. 1587-1599.
ROSELAND, M. Sustainable community development: integrating environmental, economic, and social objectives. Progress in Planning, Vol. 54, 2000. P. 73-132.

ROUSSEAU, J. The Social Contract and Other Later Political Writings. Edited and translated by Victor Gourevitch. Cambridge, U.K.: Cambridge University Press, 1997.

SCHLOSBERG, D. Reconceiving environmental justice: global movements and political theories. Environmental Politics. Vol. 13, No. 3, Autumn 2004.

SZARO, R. et al. The emergence of ecosystem management as a tool for meeting people's needs and sustaining ecosystems. Landscape and Urban Planning, 40:1-7, 1998.

THABREW, L. et tal. Environmental decision-making in multi-stakeholder contexts: applicability of life cycle thinking of development planning and implementation. Journal of Cleaner Production, Vol. 17, 2009. p. 67-76.

VIANNA, M. (Org.) Diagnóstico da cadeia produtiva da pesca marítima no Estado do Rio de Janeiro: Relatório da pesquisa. Rio de Janeiro: FAERJ: SEBRAE-RJ, 2009.

WEBLER, T. et tal. Public participation in impact assessment: a social learning perspective. Environmental Impact Assessment Review, 15:443-463, 1995.

ZHOURI, A. Justiça ambiental, diversidade cultural e accountability: desafios para a governança ambiental. RBCS, Vol. 23, no. 68, Out. 2008. 